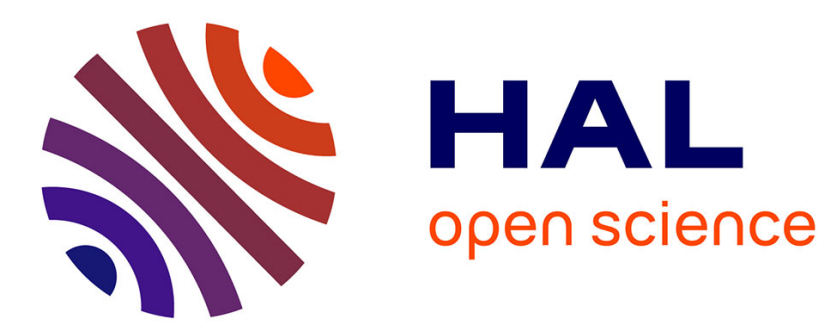

\title{
Geochemical characterization and modeling of arsenic behavior in a highly contaminated mining soil
}

Sara Bisone, Vincent Chatain, Denise Blanc, Mathieu Gautier, Rémy Bayard, Florence Sanchez, Rémy Gourdon

\section{- To cite this version:}

Sara Bisone, Vincent Chatain, Denise Blanc, Mathieu Gautier, Rémy Bayard, et al.. Geochemical characterization and modeling of arsenic behavior in a highly contaminated mining soil. Environmental Earth Sciences, 2016, 10.1007/s12665-015-5203-z . hal-01307874

\section{HAL Id: hal-01307874 https://hal.science/hal-01307874}

Submitted on 26 Apr 2016

HAL is a multi-disciplinary open access archive for the deposit and dissemination of scientific research documents, whether they are published or not. The documents may come from teaching and research institutions in France or abroad, or from public or private research centers.
L'archive ouverte pluridisciplinaire HAL, est destinée au dépôt et à la diffusion de documents scientifiques de niveau recherche, publiés ou non, émanant des établissements d'enseignement et de recherche français ou étrangers, des laboratoires publics ou privés. 


\section{Geochemical characterization and modeling of arsenic behavior in a highly contaminated mining soil}

Sara Bisone 1

Vincent Chatain 1,*

Phone +33 (0)4 72438190

Email Vincent.Chatain@insa-lyon.fr

Denise Blanc 1

Mathieu Gautier 1

Rémy Bayard 1

Florence Sanchez 2

Rémy Gourdon 1

1 LGCIE_DEEP (Déchets Eau Environnement Pollutions),

EA4126, Université de Lyon, INSA Lyon, 69621 Villeurbanne Cedex, France

2 Department of Civil and Environmental Engineering, Vanderbilt University, Station B-35 1831, Nashville, TN, 37235 USA

\section{Abstract}

The environmental assessment and management of historical mining sites contaminated with various inorganic species require a better knowledge of pollutant-bearing phases. Among elements present in mining soils, arsenic is a toxic metalloid with potential high content and high mobility capacity into the environment. The objective of this paper was to investigate the mobility and fractionation of arsenic (As) in a highly As contaminated soil (ca. $3 \mathrm{wt} \%$ ). The soil was collected from an old gold mining site in France, where mining activities and smelting processes of gold ores took place. Single and sequential chemical extraction procedures were firstly 
conducted. These leaching tests were used to assess the potential mobility of As depending on its fractionation in the contaminated soil, and also on the portion of As sorbed onto soil particles. Additionally numerical simulations were performed using the USGS software PHREEQC-3 in order to evaluate the role of adsorption on As mobilization. This multidisciplinary approach provided information on the nature of As fixation in this mining soil. Moreover the role of adsorption in the control of dissolved As was evidenced by geochemical modeling. Results showed that As appeared to be mainly (ca. $72 \mathrm{wt} \%$ ) reversibly sorbed to iron (Fe) compounds in the soil, in particular $\mathrm{Fe}$ oxyhydroxides. Consequently a potential risk of $\mathrm{As}$ mobilization exists especially under acidic and/or reducing conditions, which frequently occurs in mining environments.

AQ1

\section{Keywords}

Arsenic

Mining Soil

Fe oxyhydroxides

Geochemical modeling

Mineral assemblage

\section{Introduction}

Arsenic (As) is a toxic metalloid naturally present in the environment that comes from various sources such as volcanism and weathering of the bed rock. The As concentration in natural soils typically ranges from 0.1 to $50 \mathrm{mg} \cdot \mathrm{kg}^{-1}$ (Baker and Chesnin 1975). Anthropogenic activities also contribute to the geochemical cycling of As in a variety of ways (Huang 1994 ; Smedley and Kinniburgh 2002; Tamaki and Frankenberger 1992). Arsenic is used in agriculture as a component of pesticides, and in wood preservation and glassmaking. It is also dispersed into the environment through the burning of fossil fuels. Additionally, due to its geochemistry, As is used as an indicator element in geochemical prospecting for various types of mineral ores (gold, silver, copper, uranium, etc.) (Boyle and Jonasson 1973; Reith and McPhail 2007).

AQ2

Soils near mining sites receive significant inputs of As and heavy metals 
during mining operations and minerals processing (Azcue and Nriagu 1995; Bodénan et al. 2004; Hudson-Edwards et al. 1999; Navarro et al. 2008; Savage et al. 2000). Arsenic concentrations in tailings piles and tailingcontaminated soils can reach up to several thousand $\mathrm{mg} \cdot \mathrm{kg}^{-1}$ (Smedley and Kinniburgh 2002). However, unlike organic contaminants, As in soils cannot be decomposed chemically or biologically.

It is commonly acknowledged that total As concentration in the soil is not a good indicator of potential mobility and leaching. Chemical interactions between soil and As are important to understand its fate in the environment and choose the suitable management strategy (Bolan et al. 2014). These last years, part of the research concerned remediation (Gonzalez-Fernandez et al. 2011; Drouhot et al. 2014; Jana et al. 2012; Flakova et al. 2012). In this context, the better understanding of the fractionation and the potential of mobilization of arsenic is required and helpful to improve the efficiency of these technics.

Although a wide variety of leaching tests are available in the literature to determine the potential mobility of pollutants (Kosson et al. 2002; van der Sloot et al. 1997), very few have been designed to provide information on the nature of their fixation processes in studied matrices. On the other hand, hydrous ferric oxides (HFO) are known to be important in the retention of inorganic arsenic in soil. The interaction between HFO and ions can be described by surface complexation model (SCM) (Dzombak and Morel 1990). This approach has been successfully used to study As adsorption/desorption onto HFO in sediments, soils and groundwater (Biswas et al. 2014; Bowell 1994 ; Jiang et al. 2005 ; Lumsdon et al. 2001). Used concurrently with geochemical characterization, the modeling has proved to be useful to describe As behavior (Carrillo-Chávez et al. 2014; Coussy et al. 2010; Sracek et al. 2004).

In this context, an approach was developed based on the use of leaching tests (single and sequential chemical extraction procedures) in conjunction with a mineralogical study and a geochemical modeling. Indeed, knowledge of the pollutants operational fractionation in the studied matrix is required to better understand mechanisms regulating the leaching behavior of inorganic contaminants of interest.

The work reported in this article focused on the determination of the nature of As distribution and association to the soil constituents, and the impact of these 
characteristics on the leaching behavior observed. The scientific objective was to better understand the mechanisms regulating the leaching behavior in order to better assess and model the potential mobilization of As under the effect of environmental conditions. A further objective was to validate the experimental methodology developed for that purpose.

The correlation between mineralogy, leachability and modeling of As was examined in a contaminated soil collected from a French gold mining site. Mineralogical analyses were carried out following leaching tests to characterize the studied matrix. The numerical simulation of batch leaching experiments was performed using PHREEQC (version 3) (Parkhurst and Appelo 1999).

Our research was developed in order to better understand the distribution of As in a representative sample by combining (i) experimental data obtained from single and sequential chemical extraction procedures (leaching tests), (ii) mineralogical characteristics determined with various analytical tools and (iii) geochemical modeling. This multidisciplinary approach tends to improve geochemical assemblage definition and As comportment.

\section{Materials and methods}

\section{Sampling and preparation of the soil}

An As-contaminated soil collected from a gold mining site in France, where mining activities and smelting processes of gold ores took place until 2004, was used for the study (Chatain 2004). It was already known to present high concentrations of As (Bayard et al. 2006).

From the soil top surface (sampling depth: 5-35 cm), four representative soil samples, of about $50 \mathrm{~kg}$ were collected from the site. Prior to characterizations and liquid-solid partitioning experiments, the soil samples were air-dried at room temperature $\left(20 \pm 3{ }^{\circ} \mathrm{C}\right)$ for 1 day, sieved through a stainless steel $2 \mathrm{~mm}$ mesh sieve to remove coarse debris and gravel, homogenized, and finally stored at $4{ }^{\circ} \mathrm{C}$ in the dark (Chatain et al. 2005a).

\section{Chemical and mineralogical characterization}

The natural $\mathrm{pH}$ of the soil was measured in a 10:1 mixture of soil to deionized water after a contact period of $48 \mathrm{~h}$ (SR003.1 protocol, Kosson et al. 2002) using a WTW ${ }^{\circledR}$ combined glass electrode. The redox potential (ORP) was 
measured in the same soil slurry using a Radiometer analytical ${ }^{(B)}$ platinumkalomel electrode (Pt-Ag/AgCl, +197 mV vs. NHE).

After mineralization by acid digestion (AFNOR 1996), total soil concentration of trace elements and major constituents was determined by Inductively Coupled Plasma Optical Emission Spectrometry (ICP-OES, Jobin-Yvon Ultima $2^{\circledR}$ ).

\section{X-ray diffraction}

Three replicates of the soil fraction $<2 \mathrm{~mm}$ were ground to a fine powder $(<50 \mu \mathrm{m})$ and studied with a SIEMENS ${ }^{\circledR}$ D500 X-ray diffractometer (XRD) equipped with a copper anticathode. The samples were scanned on a reflection angle $(2 \theta)$ from $3^{\circ}$ to $70^{\circ}$ at a scan rate of $0.02^{\circ} 2 \theta / \mathrm{s}$. Results were processed using the DIFFRAC ${ }^{\text {Plus }}$ EVA $\left(\right.$ ) software $\left(\right.$ BRUKER AXS $\left.{ }^{\circledR}\right)$ and the ICDD ${ }^{\circledR}$ database (International Centre for Diffraction Data).

Scanning electron microscopy equipped for energy dispersive spectroscopy

Mineralogical investigation was also performed on two replicates of the same fraction $(<2 \mathrm{~mm})$ by scanning electron microscope (SEM, JEOL ${ }^{\circledR} 840 \mathrm{~A} \mathrm{LGS}$ ) coupled with an X-ray energy dispersive spectrometer (EDS). Samples were prepared by pasting the soil particles on an adhesive tape placed on a stub (sample holder of the SEM). Sample coating with a conductive material was not required. The backscattered electron (BSE) mode was used with a voltage of $20 \mathrm{kV}$.

\section{Leaching tests}

A sequential chemical extraction specifically adapted by Matera et al. (2003) to study As-bearing phases on amorphous and crystal iron was chosen. The seven following arsenic fractions were extracted: (F1) soluble in $\mathrm{MgCl}_{2}$ $\left(1 \mathrm{~mol} \cdot \mathrm{L}^{-1}\right)$ at $\mathrm{pH} 7 ;(\mathrm{F} 2)$ bound to carbonates $\left(\mathrm{CH}_{3} \mathrm{COONa}\right.$ $\left(1 \mathrm{~mol} \cdot \mathrm{L}^{-1}\right) / \mathrm{CH}_{3} \mathrm{COOH}$ pure at $\left.\mathrm{pH} 5\right) ;(\mathrm{F} 3-\mathrm{Mn})$ bound to Mn-oxides $\left(\mathrm{NH}_{2} \mathrm{OH} \cdot \mathrm{HCl}\left(0.04 \mathrm{~mol} \cdot \mathrm{L}^{-1}\right)\right.$ in $\mathrm{CH}_{3} \mathrm{COOH} 25 \%$ at $\left.\mathrm{pH} 2\right)(\mathrm{F} 3-\mathrm{Fe}(\mathrm{a}))$ bound to amorphous Fe oxides $\left(\left(\mathrm{NH}_{4}\right)_{2} \mathrm{C}_{2} \mathrm{O}_{4} \cdot \mathrm{H}_{2} \mathrm{O}\left(0.2 \mathrm{~mol} \cdot \mathrm{L}^{-1}\right) / \mathrm{H}_{2} \mathrm{C}_{2} \mathrm{O}_{4}\right.$ $\left(0.2 \mathrm{~mol} \cdot \mathrm{L}^{-1}\right)$ at $\left.\mathrm{pH} 2\right)$; ( $\left.\mathrm{F} 3-\mathrm{Fe}(\mathrm{c})\right)$ bound to crystalline $\mathrm{Fe}$ oxides $\left(\left(\mathrm{NH}_{4}\right)_{2} \mathrm{C}_{2} \mathrm{O}_{4} \cdot \mathrm{H}_{2} \mathrm{O}\left(0.2 \mathrm{~mol} \cdot \mathrm{L}^{-1}\right) / \mathrm{H}_{2} \mathrm{C}_{2} \mathrm{O}_{4}\left(0.2 \mathrm{~mol} \cdot \mathrm{L}^{-1}\right) / \mathrm{C}_{6} \mathrm{H}_{8} \mathrm{O}_{6}\right.$ $\left(0.1 \mathrm{~mol} \cdot \mathrm{L}^{-1}\right)$ at $\left.\mathrm{pH} 2\right)$; (F4) bound to organic matter and sulfides $\left(\mathrm{HNO}_{3}\right.$ and $\mathrm{H}_{2} \mathrm{O}_{2} 30 \%$ at $\mathrm{pH} 2$; and $\mathrm{CH}_{3} \mathrm{COONH}_{4}\left(3.2 \mathrm{~mol} \cdot \mathrm{L}^{-1}\right.$ ) in $\left.\mathrm{HNO}_{3} 20 \%\right)$; (F5) residual fraction (obtained by difference after total digestion). 
Single extraction techniques were also performed to verify that As adsorption on Fe oxyhydroxides was the major process of As trapping in the soil (Clozel et al. 2002). These extractions were carried out in triplicate using $1 \mathrm{~mol} \cdot \mathrm{L}^{-1}$ sodium hydroxide $(\mathrm{NaOH})$ solution, and $0.1 \mathrm{~mol} \cdot \mathrm{L}^{-1}$ dipotassium hydrogen orthophosphate $\left(\mathrm{K}_{2} \mathrm{HPO}_{4}\right)$ solution. A liquid/solid $(\mathrm{L} / \mathrm{S})$ ratio of $10 \mathrm{~mL} \cdot \mathrm{g}^{-1}$ and a contact time of $48 \mathrm{~h}$ were used.

Batch leaching experiments were conducted following the SR002.1 protocol (Kosson et al. 2002). Under ambient conditions, $10 \mathrm{~g}$ of soil sample and $100 \mathrm{ml}$ of prepared solutions were mixed for $48 \mathrm{~h}$ (L/S ratio of $10 \mathrm{~mL} / \mathrm{g}$ of dried soil). $\mathrm{HCl}$ and $\mathrm{NaOH}$ solutions of varying concentrations were used as leachants in order to obtain a range of $\mathrm{pH}$ varying from 1 to 13.

\section{Leachate analyses}

All leachates were filtered through $0.45 \mu \mathrm{m}$ pore size acetate-cellulose Whatman ${ }^{\circledR}$ membranes. They were subsequently analyzed for concentrations of the constituents of interest using ICP-OES. Sulfates and chlorides were analyzed using IC (ion chromatography, Dionex DX320 HPIC ${ }^{\circledR}$ ). Total organic carbon (TOC) in solution was measured using a TOC analyzer (Total Organic Carbon analyzer, Shimadzu TOC-5000A ${ }^{\circledR}$ ).

\section{Geochemical modeling}

The PHREEQC program is based on the calculation of equilibrium between aqueous solutions and minerals, gases, solid solutions, exchangers, and sorption surfaces. As suggested by Peyronnard et al. (2009), a simplified mineral assemblage was defined on the basis of the mineralogical study (XRD and SEM analysis) and chemical characterization. The acid attack was simulated on the assemblage by adding nitric acid or sodium hydroxide. Finally, quantification of minerals was optimized by comparing simulated curves to experimental data in a reiterated process.

Simulation was performed on a $1 \mathrm{~L}$ volume of liquid, which means that the solid assemblage should represent $100 \mathrm{~g}$ of soil to comply with the L/S ratio of the leaching experiment. During simulation, the equilibrium between liquid and solid was reached and no gases were considered.

The geochemical model was developed to evaluate the role of adsorption in As solubilization. The assemblage which best fit buffer capacity and solution concentration was used to compare two models: with and without considering 
adsorption. The adsorption phenomena is modelled with a surface complexation model: the DDL (diffuse-double layer) (Dzombak and Morel 1990 ), already incorporated in PHREEQC, was used. From the mineralogical analysis data, it was assumed that the dominant adsorption/desorption phase was hydrous-ferric oxide (HFO). In the DDL, the major surface complexes for $\mathrm{As}(\mathrm{III})$ and $\mathrm{As}(\mathrm{V})$ are $\equiv \mathrm{FeH}_{2} \mathrm{AsO}_{3}$ and $\equiv \mathrm{FeHAsO}_{4}{ }^{-}$, respectively. With the decrease in $\mathrm{pH}$ the formation of $\equiv \mathrm{FeHAsO}_{4}{ }^{-}$is favored, whereas at higher $\mathrm{pH}$ $\equiv \mathrm{FeH}_{2} \mathrm{AsO}_{3}$ is prevalent.

The Lawrence Livermore National Library (1lnl) thermodynamic database supplied with PHREEQC was used for solubility products and dissolution reactions of mineral phases. Surface complexation constants from Dzombak and Morel (1990) are already implemented in the llnl database for reactions between ferrihydrite and major cations ( $\mathrm{Ca}, \mathrm{S}, \mathrm{Ba}, \mathrm{Cd}, \mathrm{Zn}, \mathrm{Cu}, \mathrm{Pb}, \mathrm{Mg}, \mathrm{Mn}$, $\mathrm{Fe}$ ) and anions. The database was modified by adding surface complexation constants for arsenate and arsenite on HFO from the minteq.v4 database. $\mathrm{Fe}(\mathrm{OH})_{3}(\mathrm{am})$ phase (Hummel et al. 2002), reactions involving $\mathrm{H}_{3} \mathrm{AsO}_{3}$ and their corresponding equilibrium constants were included as well. Table 1 reports the surface complexation constants for sorption of As on HFO.

\section{Table 1}

Adsorption reactions and equilibrium constant of surface complexation of As with HFO

\begin{tabular}{|l|l|}
\hline Adsorption reaction & log K \\
\hline$\equiv \mathrm{FeOH}+\mathrm{H}_{3} \mathrm{AsO}_{4} \leftrightarrow \equiv \mathrm{FeH}_{2} \mathrm{AsO}_{4}+\mathrm{H}_{2} \mathrm{O}$ & 8.67 \\
\hline$\equiv \mathrm{FeOH}+\mathrm{H}_{3} \mathrm{AsO}_{4} \leftrightarrow \equiv \mathrm{FeHAsO}_{4}^{-}+\mathrm{H}_{2} \mathrm{O}+\mathrm{H}^{+}$ & 2.99 \\
\hline$\equiv \mathrm{FeOH}+\mathrm{H}_{3} \mathrm{AsO}_{4} \leftrightarrow \equiv \mathrm{FeOHAsO}_{4}{ }^{3-}+3 \mathrm{H}^{+}$ & -10.15 \\
\hline$\equiv \mathrm{FeOH}+\mathrm{H}_{3} \mathrm{AsO}_{3} \leftrightarrow \equiv \mathrm{FeH}_{2} \mathrm{AsO}_{3}+\mathrm{H}_{2} \mathrm{O}$ & 5.41 \\
\hline$\equiv \mathrm{FeOH}+\mathrm{H}_{3} \mathrm{AsO}_{4} \leftrightarrow \equiv \mathrm{FeAsO}_{4}{ }^{2-}+\mathrm{H}_{2} \mathrm{O}+2 \mathrm{H}^{+}$ & -4.70 \\
\hline
\end{tabular}

\section{Results and discussion}

\section{Chemical characterization}

The major physicochemical characteristics and the elemental total concentrations as determined by acidic digestion of the studied soil are summarized in Table 2 . 


\section{Table 2}

Physicochemical characteristics (L/S ratio: $10 \mathrm{~mL} \cdot \mathrm{g}^{-1}$; contact time: $48 \mathrm{~h}$ ) and concentration of trace elements as determined by acid digestion of the studied soil

\begin{tabular}{|l|l|}
\hline Water content $(\mathrm{wt} \%)$ & 10 \\
\hline $\mathrm{pH}\left(\mathrm{H}_{2} \mathrm{O}\right)$ & 6.5 \\
\hline $\mathrm{ORP}(\mathrm{mV}$ vs. NHE) & 400 \\
\hline $\mathrm{Si}(\mathrm{wt} \%)$ & 20.3 \\
\hline $\mathrm{Fe}(\mathrm{wt} \%)$ & 8.9 \\
\hline $\mathrm{Al}(\mathrm{wt} \%)$ & 4.3 \\
\hline $\mathrm{Ca}(\mathrm{wt} \%)$ & 3.7 \\
\hline $\mathrm{As}\left(\mathrm{mg} \cdot \mathrm{kg}^{-1}\right)$ & 27,700 \\
\hline $\mathrm{Cu}\left(\mathrm{mg} \cdot \mathrm{kg}^{-1}\right)$ & 1700 \\
\hline $\mathrm{Pb}\left(\mathrm{mg} \cdot \mathrm{kg}^{-1}\right)$ & 800 \\
\hline $\mathrm{Zn}\left(\mathrm{mg} \cdot \mathrm{kg}^{-1}\right)$ & 400 \\
\hline
\end{tabular}

The soil was mainly characterized by a water content of $10,3 \mathrm{wt} \%$ of As, 9 wt $\%$ of $\mathrm{Fe}$ and $1.9 \mathrm{wt} \%$ of total organic carbon. Its natural $\mathrm{pH}$ and ORP measured after $48 \mathrm{~h}$ of contact with deionized water at a $\mathrm{L} / \mathrm{S}$ ratio of $10 \mathrm{~mL} / \mathrm{g}$, were 6.5 and $+400 \mathrm{mV}$ vs. NHE, respectively. Moreover, a very low soluble $(0.016 \mathrm{wt} \%)$ fraction of As was obtained from the single extraction procedure using deionized water as the extractant.

\section{Mineralogical characterization}

This characterization was achieved by using scanning electron microscopy coupled with an EDS analyzer and XRD analysis. Results from the XRD analysis (Table 3 ) indicated that the soil was mainly composed of quartz, gypsum, feldspars, micas (as muscovite), calcite, and dolomite.

\section{Table 3}

Mineral composition by XRD analysis (relative abundance: ++++ very abundant; +++ abundant; ++ present; + traces)

\section{Mineral}

Quartz

\section{Abundance}

$++++$ 


\begin{tabular}{|l|l|}
\hline Mineral & Abundance \\
\hline Micas & ++ \\
\hline Feldspar & ++ \\
\hline Chlorite & + \\
\hline Kaolinite & + \\
\hline Calcite & ++ \\
\hline Dolomite & ++ \\
\hline Gypsum & +++ \\
\hline Jarosite & ++ \\
\hline Hematite & + \\
\hline Scorodite & + \\
\hline
\end{tabular}

XRD analyses indicated the presence of traces of hematite, jarosite and scorodite, which are the common pyrite weathering products with which As can be typically bound (Clozel et al. 2002). The absence of residual mixed sulfide phases in the soil could be due to the weathering and oxidation of pyritic minerals during the post-mining period.

Microscopy analyses performed using the BSE images by SEM coupled with EDS microanalysis can be used to complement the XRD analysis. The major minerals identified were quartz, gypsum, and particles containing Fe and As, with a composition in accordance with XRD results. A close similarity between the arsenic and iron cartography was observed in SEM results (Fig. 1).

Fig. 1

SEM-EDX mapping of the $0.2-2 \mathrm{~mm}$ fraction of the soil (12X) 

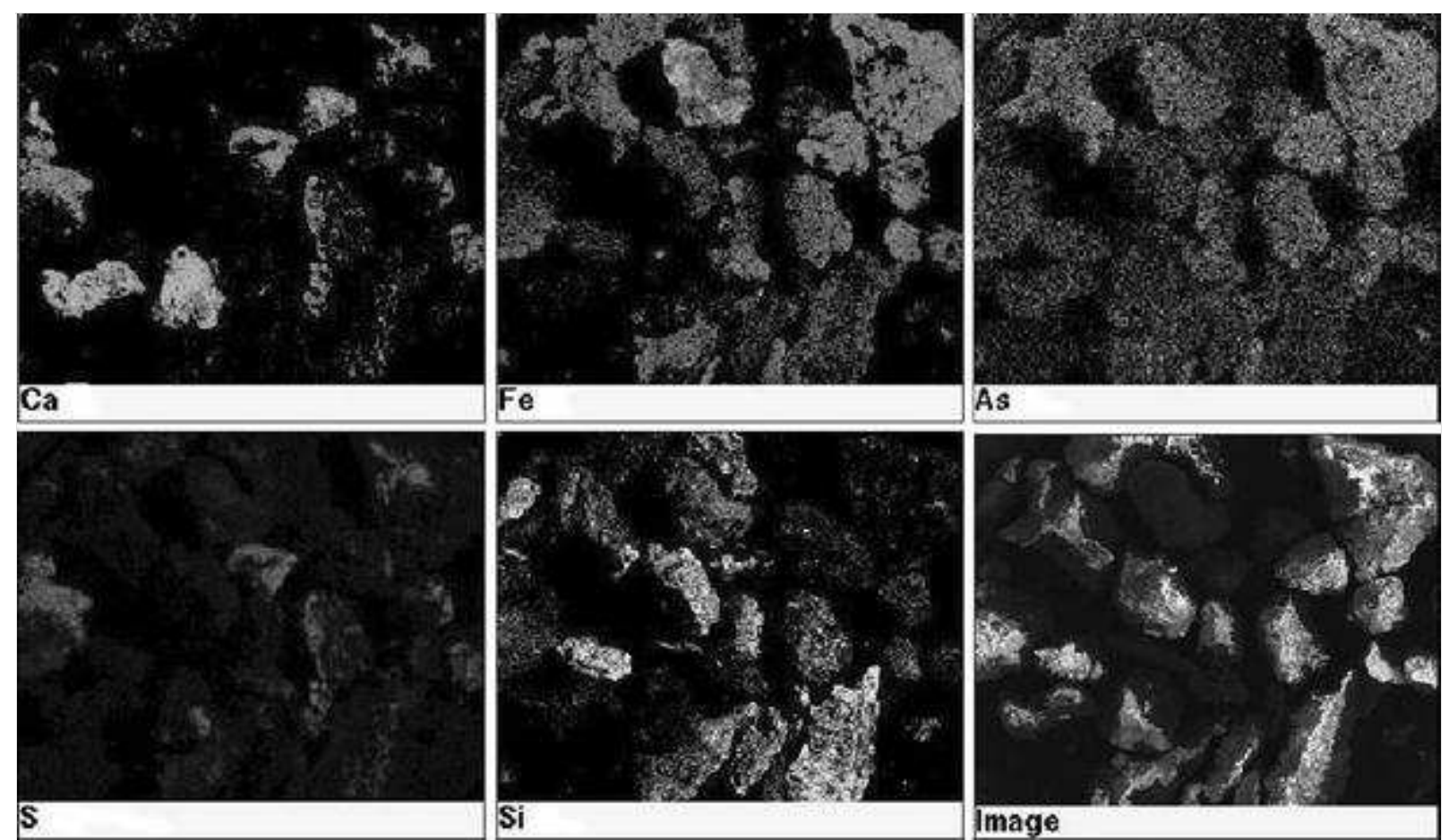

\section{Leaching behavior}

The results of sequential extractions are summarized in Fig. 2. The largest portion of As (about $66 \mathrm{wt} \%$ ) was extracted as fraction $\mathrm{F} 3-\mathrm{Fe}$ (a) (bound to amorphous Fe oxides). Globally the first six fractions represented about 73 wt $\%$ of the total As and only $27 \mathrm{wt} \%$ was in the residual fraction, and then strongly bound to the soil matrix. A very low fraction of As and Fe (i.e., <1 wt $\%$ ) was extracted as exchangeable and bound-to-carbonates fractions. These results confirmed that As was mainly bound on soil amorphous oxyhydroxide particles, as previously shown by the results from XRD and SEM.

\section{Fig. 2}

Sequential chemical extractions performed on the $<2 \mathrm{~mm}$ fraction of the soil (conc. in $\mathrm{wt} \%$ ) 


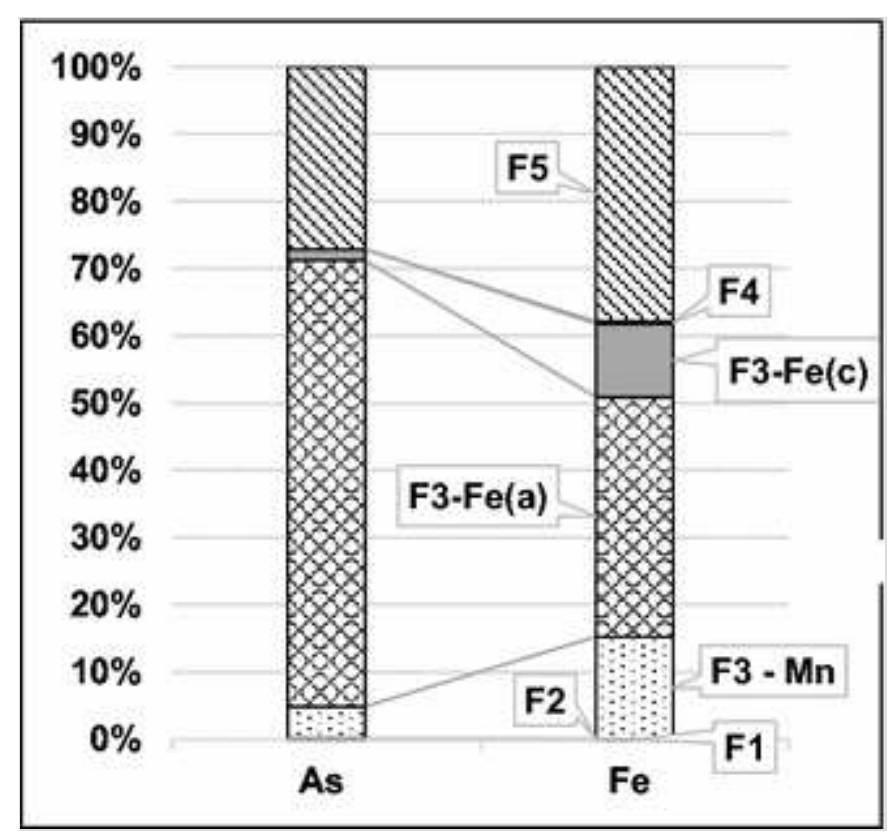

The results obtained from single extractions, using $1 \mathrm{~mol} \cdot \mathrm{L}^{-1} \mathrm{NaOH}$ solution, and $0.1 \mathrm{~mol} \cdot \mathrm{L}^{-1} \mathrm{~K}_{2} \mathrm{HPO}_{4}$ solution, are summarized in Table 4 . They are compared with those acquired during single extraction using deionized water (natural).

\section{Table 4}

Results from single extractions (LS ratio: $10 \mathrm{~mL} \cdot \mathrm{g}^{-1}$; contact time: $48 \mathrm{~h}$ )

\begin{tabular}{|l|l|l|l|l|}
\hline Extracting solution & $\begin{array}{l}\text { As (conc. in } \\
\text { wt\%) }\end{array}$ & $\begin{array}{l}\text { Fe (conc. in } \\
\mathbf{w t \%})\end{array}$ & pH & $\begin{array}{l}\text { ORP (mV vs. } \\
\text { NHE) }\end{array}$ \\
\hline Deionized water & $1.60 \times 10^{-3}$ & $1.0 \times 10^{-4}$ & 6.5 & +400 \\
\hline $\begin{array}{l}1 \mathrm{~mol} \cdot \mathrm{L}^{-1} \mathrm{NaOH} \\
\text { solution }\end{array}$ & 73.51 & $1.7 \times 10^{-1}$ & 13.8 & +60 \\
\hline $\begin{array}{l}0.1 \mathrm{~mol} \cdot \mathrm{L}^{-1} \mathrm{~K}_{2} \mathrm{HPO}_{4} \\
\text { solution }\end{array}$ & 4.89 & $3.40 \times 10^{-3}$ & 7.5 & +430 \\
\hline
\end{tabular}

Concerning $\mathrm{NaOH}$ extraction, about $74 \mathrm{wt} \%$ of the total As was extracted within these extreme conditions of $\mathrm{pH}$ (ca. 14). A mechanism of As desorption from the $\mathrm{Fe}$ oxyhydroxide surface by competition with $\mathrm{OH}^{-}$ions might explain the abrupt increase in As extractability (Carbonell-Barrachina et al. 1999; Yang et al. 2002). Fe solubility remained very low (ca. 0.2 wt\% of the total Fe content). Fe solubility might have been controlled by $\mathrm{Fe}$ oxyhydroxide precipitates.

These results suggest that most of the As present in the soil is sorbed onto $\mathrm{Fe}$ oxyhydroxides, which is consistent with the mineralogical analysis and 
sequential extraction. The remaining fraction (ca. $26 \%$ of the total As content) can be considered to represent the part co-precipitated with Fe and/or bound to resistant compounds (i.e., silicates or sulfides).

The results of As extraction from the contaminated soil by $\mathrm{K}_{2} \mathrm{HPO}_{4}$ solution are also shown in Table 4 . The addition of this solution was found to have no significant effect on $\mathrm{pH}$ and ORP conditions and Fe release, compared to those obtained with deionized water (natural conditions). However, a drastic increase in As solubilization (as much as 400-fold at a $\mathrm{pH}$ value about 7), and in phosphate adsorption onto Fe oxyhydroxides (ca. $76 \%$ ) was evidenced.

These results are consistent with studies performed by Alam et al. (2001) and Clozel et al. (2002), confirming that As is for the most part reversibly sorbed onto Fe oxyhydroxides.

\section{Contaminant mobility as a function of $\mathrm{pH}$ and geochemical modeling}

Batch leaching tests showed a low solubility of As between pH 3 and 7.5. Mobility increased with acid and alkaline conditions with a maximum for $\mathrm{pH}$ below 1 .

All minerals observed in the XRD analysis (Table 3 ) were included in the model. The presence of amorphous hydroxide was evidenced by previous studies (Bayard et al. 2006; Chatain et al. 2003, 2005b; Clozel et al. 2002) and confirmed by the sequential extraction presented in section "Leaching behavior". It was therefore introduced in the assemblage as amorphous $\mathrm{Fe}(\mathrm{OH})_{3}$. Arsenic was introduced as arsenopyrite (present in the original minerals) and scorodite, a secondary mineral which currently occurs in waste rocks rich in arsenopyrite and/or arsenian pyrite as a weathering product (Nordstrom and Parks 1987; Paktunc and Bruggeman 2010). Lastly, the model was set so that hematite and iron(III) hydroxide could dissolve but not precipitate. Since the time contact of the experiment was relatively short (48 h), the equilibrium condition of PHREEQC calculations would overestimate the precipitation of these phases. For the same reason, the assemblage does not represent the entire soil mineralogy but the reactive fraction, bringing the total mass of the mineral assemblage to $41.2 / 100 \mathrm{~g}$. Table 5 presents reactions, equilibrium constants and initial mass of minerals used to represent the leaching behavior of the soil. 


\section{Table 5}

Reactions, equilibrium constant and initial mass of assemblage minerals

\begin{tabular}{|c|c|c|c|}
\hline Mineral & Dissolution reaction & $\log K s p$ & $\begin{array}{l}\text { Initial } \\
\text { mass (g) }\end{array}$ \\
\hline Quartz & $\mathrm{SiO}_{2}=\mathrm{SiO}_{2}$ & -3.9993 & 12.0168 \\
\hline Kaolinite & $\begin{array}{l}\mathrm{Al}_{2} \mathrm{Si}_{2} \mathrm{O}_{5}(\mathrm{OH})_{4}+6 \mathrm{H}^{+}=2 \mathrm{Al}^{3+}+2 \\
\mathrm{SiO}_{2}+5 \mathrm{H}_{2} \mathrm{O}\end{array}$ & 6.8101 & 0.2582 \\
\hline K-Feldspar & $\begin{array}{l}\mathrm{KAlSi}_{3} \mathrm{O}_{8}+4 \mathrm{H}^{+}=+\mathrm{Al}^{3+}+\mathrm{K}^{+}+2 \\
\mathrm{H}_{2} \mathrm{O}+3 \mathrm{SiO}_{2}\end{array}$ & -0.2753 & 4.1745 \\
\hline Muscovite & $\begin{array}{l}\mathrm{KAl}_{3} \mathrm{Si}_{3} \mathrm{O}_{10}(\mathrm{OH})_{2}+10 \mathrm{H}^{+}=\mathrm{K}^{+}+3 \\
\mathrm{Al}^{3+}+3 \mathrm{SiO}_{2}+6 \mathrm{H}_{2} \mathrm{O}\end{array}$ & 13.5858 & 0.0398 \\
\hline Chamosite-7A & $\begin{array}{l}\mathrm{Fe}_{2} \mathrm{Al}_{2} \mathrm{SiO}_{5}(\mathrm{OH})_{4}+10 \mathrm{H}^{+}=\mathrm{SiO}_{2}+2 \\
\mathrm{Al}^{3+}+2 \mathrm{Fe}^{2+}+7 \mathrm{H}_{2} \mathrm{O}\end{array}$ & 32.8416 & 0.0342 \\
\hline Clinochlore-7A & $\begin{array}{l}\mathrm{Mg}_{5} \mathrm{Al}_{2} \mathrm{Si}_{3} \mathrm{O}_{10}(\mathrm{OH})_{8}+16 \mathrm{H}^{+}=2 \\
\mathrm{Al}^{3+}+3 \mathrm{SiO}_{2}+5 \mathrm{Mg}^{2+}+12 \mathrm{H}_{2} \mathrm{O}\end{array}$ & 70.6124 & 0.2779 \\
\hline Cronstedtite-7A & $\begin{array}{l}\mathrm{Fe}_{2} \mathrm{Fe}_{2} \mathrm{SiO}_{5}(\mathrm{OH})_{4}+10 \mathrm{H}^{+}=\mathrm{SiO}_{2}+2 \\
\mathrm{Fe}^{2+}+2 \mathrm{Fe}^{3+}+7 \mathrm{H}_{2} \mathrm{O}\end{array}$ & 16.2603 & 0.0400 \\
\hline Ripidolite-14A & $\begin{array}{l}\mathrm{Mg}_{3} \mathrm{Fe}_{2} \mathrm{Al}_{2} \mathrm{Si}_{3} \mathrm{O}_{10}(\mathrm{OH})_{8}+16 \mathrm{H}^{+}=2 \\
\mathrm{Al}^{3+}+2 \mathrm{Fe}^{2+}+3 \mathrm{Mg}^{2+}+3 \mathrm{SiO}_{2}+12 \\
\mathrm{H}_{2} \mathrm{O}\end{array}$ & 60.9638 & 0.0619 \\
\hline Gypsum & $\mathrm{CaSO}_{4} \cdot 2 \mathrm{H}_{2} \mathrm{O}=\mathrm{Ca}^{2+}+\mathrm{SO}_{4}^{2-}+2 \mathrm{H}_{2} \mathrm{O}$ & -4.4823 & 10.3320 \\
\hline Jarosite & $\begin{array}{l}\mathrm{KFe}_{3}\left(\mathrm{SO}_{4}\right)_{2}(\mathrm{OH})_{6}+6 \mathrm{H}^{+}=\mathrm{K}^{+}+2 \\
\mathrm{SO}_{4}{ }^{2-}+3 \mathrm{Fe}^{3+}+6 \mathrm{H}_{2} \mathrm{O}\end{array}$ & -9.3706 & 0.0501 \\
\hline Calcite & $\mathrm{CaCO}_{3}+\mathrm{H}^{+}=\mathrm{Ca}^{2+}+\mathrm{HCO}_{3}^{-}$ & 1.8487 & 1.0009 \\
\hline Dolomite & $\begin{array}{l}\mathrm{CaMg}\left(\mathrm{CO}_{3}\right)_{2}+2 \mathrm{H}^{+}=\mathrm{Ca}^{2+}+\mathrm{Mg}^{2+}+2 \\
\mathrm{HCO}_{3}^{-}\end{array}$ & 2.5135 & 0.9220 \\
\hline Tenorite & $\mathrm{CuO}+2 \mathrm{H}^{+}=\mathrm{Cu}^{2+}+\mathrm{H}_{2} \mathrm{O}$ & 7.6560 & 0.0716 \\
\hline Hematite & $\mathrm{Fe}_{2} \mathrm{O}_{3}+6 \mathrm{H}^{+}=2 \mathrm{Fe}^{3+}+3 \mathrm{H}_{2} \mathrm{O}$ & 0.1086 & 3.1940 \\
\hline $\begin{array}{l}\mathrm{Fe}(\mathrm{OH})_{3} \\
\text { (amorphous) }\end{array}$ & $\mathrm{Fe}(\mathrm{OH})_{3}+3 \mathrm{H}^{+}=\mathrm{Fe}^{3+}+3 \mathrm{H}_{2} \mathrm{O}$ & 5.0000 & 6.4128 \\
\hline Pyrite & $\begin{array}{l}\mathrm{FeS}_{2}+\mathrm{H}_{2} \mathrm{O}=+0.25 \mathrm{H}^{+}+0.25 \\
\mathrm{SO}_{4}^{2-}+\mathrm{Fe}^{2+}+1.75 \mathrm{HS}^{-}\end{array}$ & -24.6534 & 0.0120 \\
\hline Chalcopyrite & $\mathrm{CuFeS}_{2}+2 \mathrm{H}^{+}=\mathrm{Cu}^{2+}+\mathrm{Fe}^{2+}+2 \mathrm{HS}^{-}$ & -32.5638 & 0.0220 \\
\hline
\end{tabular}

Except for $\mathrm{Fe}(\mathrm{OH})_{3}(\mathrm{am})$ (Hummel et al. 2002), all log Ksp values come from the Lawrence Livermore National Laboratory (1lnl) database supplied with PhreeqC ${ }^{\circledR}$ 


\begin{tabular}{|l|l|l|l|}
\hline Mineral & Dissolution reaction & log Ksp & $\begin{array}{l}\text { Initial } \\
\text { mass (g) }\end{array}$ \\
\hline \begin{tabular}{l|l} 
Arsenopyrite \\
$\mathrm{FeAsS}+1.5 \mathrm{H}_{2} \mathrm{O}+0.5 \mathrm{H}^{+}=0.5$ \\
$\mathrm{AsH}_{3}+0.5 \mathrm{H}_{2} \mathrm{AsO}_{3}^{-}+\mathrm{Fe}^{2+}+\mathrm{HS}^{-}$
\end{tabular} & -14.4453 & 0.0163 \\
\hline $\begin{array}{l}\text { Scorodite } \\
\mathrm{FeAsO}_{4} \cdot 2 \mathrm{H}_{2} \mathrm{O}=\mathrm{Fe}^{3+}+\mathrm{AsO}_{4}^{3-}+2\end{array}$ & -20.249 & 2.3078 \\
\hline $\begin{array}{l}\text { Except for } \mathrm{Fe}(\mathrm{OH})_{3}(\mathrm{am})(\mathrm{Hummel} \text { et al. 2002), all log Ksp values come from the } \\
\text { Lawrence Livermore } \mathrm{National} \mathrm{Laboratory} \mathrm{(llnl)} \mathrm{database} \mathrm{supplied} \mathrm{with} \mathrm{PhreeqC}\end{array}$
\end{tabular}

As recommended by Dzombak and Morel (1990) a specific surface area of $600 \mathrm{~m}^{2} \cdot \mathrm{g}^{-1}$ was defined, while surface density was adjusted to match batch experiments. A density of 0.09 sites $\cdot \mathrm{mol}^{-1}$ was chosen for strong sites and 0.5 sites $\cdot \mathrm{mol}^{-1}$ for the weak sites. In this respect, Sracek et al. (2004) pointed out that in many cases, the quantity of Fe(III) oxides and hydroxides indicated by mineralogical methods poorly matches modeled data and the amount of adsorbent has to be adjusted accordingly.

The best fitting assemblage was used to evaluate the role of adsorption in As release. In Fig. 3, S, Fe and As experimental solubility (Exp.) as a function of pH was compared with their solubility estimated by two models: without (Model 1) and with (Model 2) adsorption.

Fig. 3

$\mathrm{S}(\mathbf{a}), \mathrm{Fe}$ (a) and As (a) solubility as a function of $\mathrm{pH}\left(\mathrm{L} / \mathrm{S}\right.$ ratio, $\left.10 \mathrm{~mL} \cdot \mathrm{g}^{-1}\right)$. Experimental (Exp.) and modeled data: without surface complexation (Model 1) and with surface complexation (Model 2) 

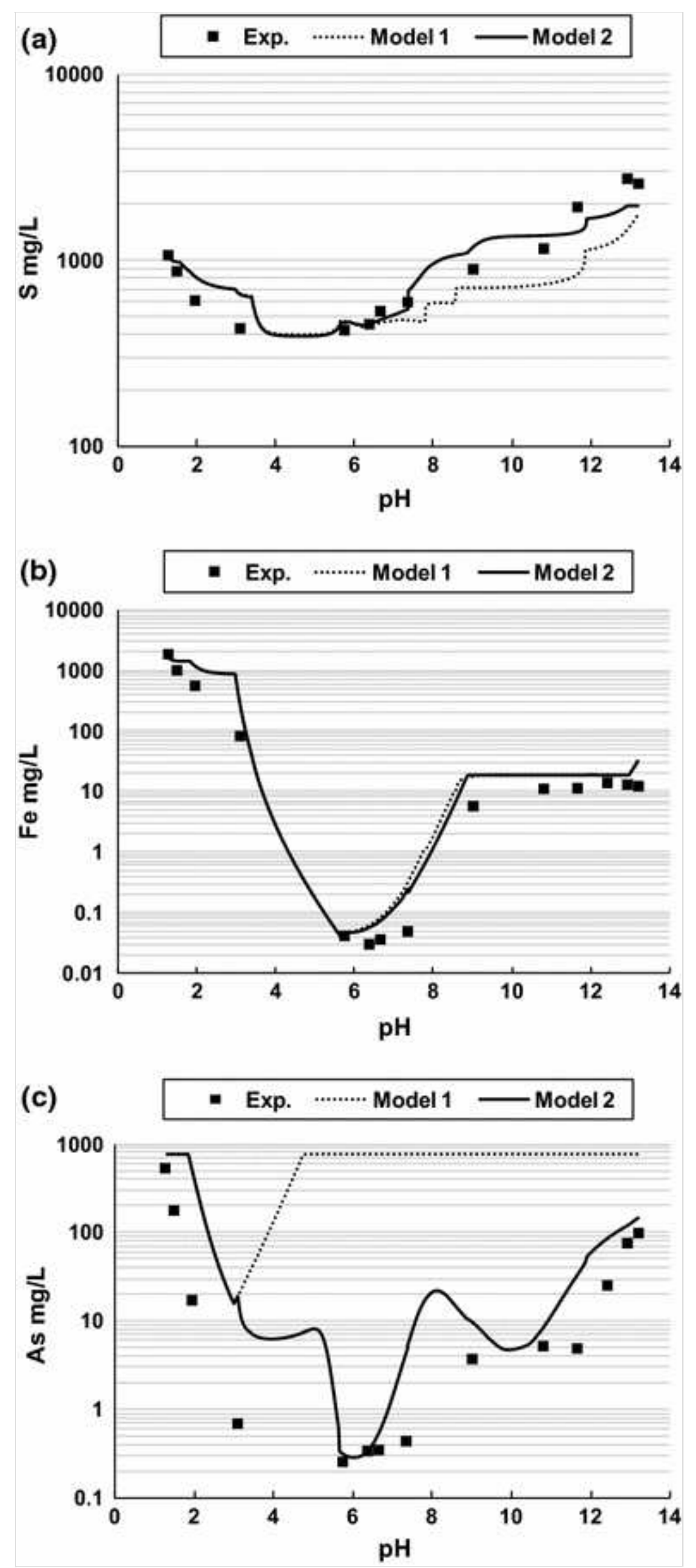

The behavior of S (Fig. 3a) and Fe (Fig. 3b) was well correlated to experimental data whether adsorption was used or not. For As (Fig. 3c), 
between $\mathrm{pH} 1$ and 3, the two models identically matched experimental data. Then, when adsorption was neglected (Model 1), soluble As increased substantially from $\mathrm{pH} 3-5$ because of the total dissolution of arsenopyritescorodite (Fig. 4 a) and scoroditearsenopyrite (Fig. 4b), which SI values became negative. Consequently, As was overestimated in Model 1 for $\mathrm{pH}$ values greater than 3 .

\section{Fig. 4}

Saturation indices of arsenopyritescorodite (a) and scoroditearsenopyrite (b) as a function of $\mathrm{pH}\left(\mathrm{L} / \mathrm{S}\right.$ ratio, $\left.10 \mathrm{~mL} \cdot \mathrm{g}^{-1}\right)$ calculated for model with surface complexation (Model 2)
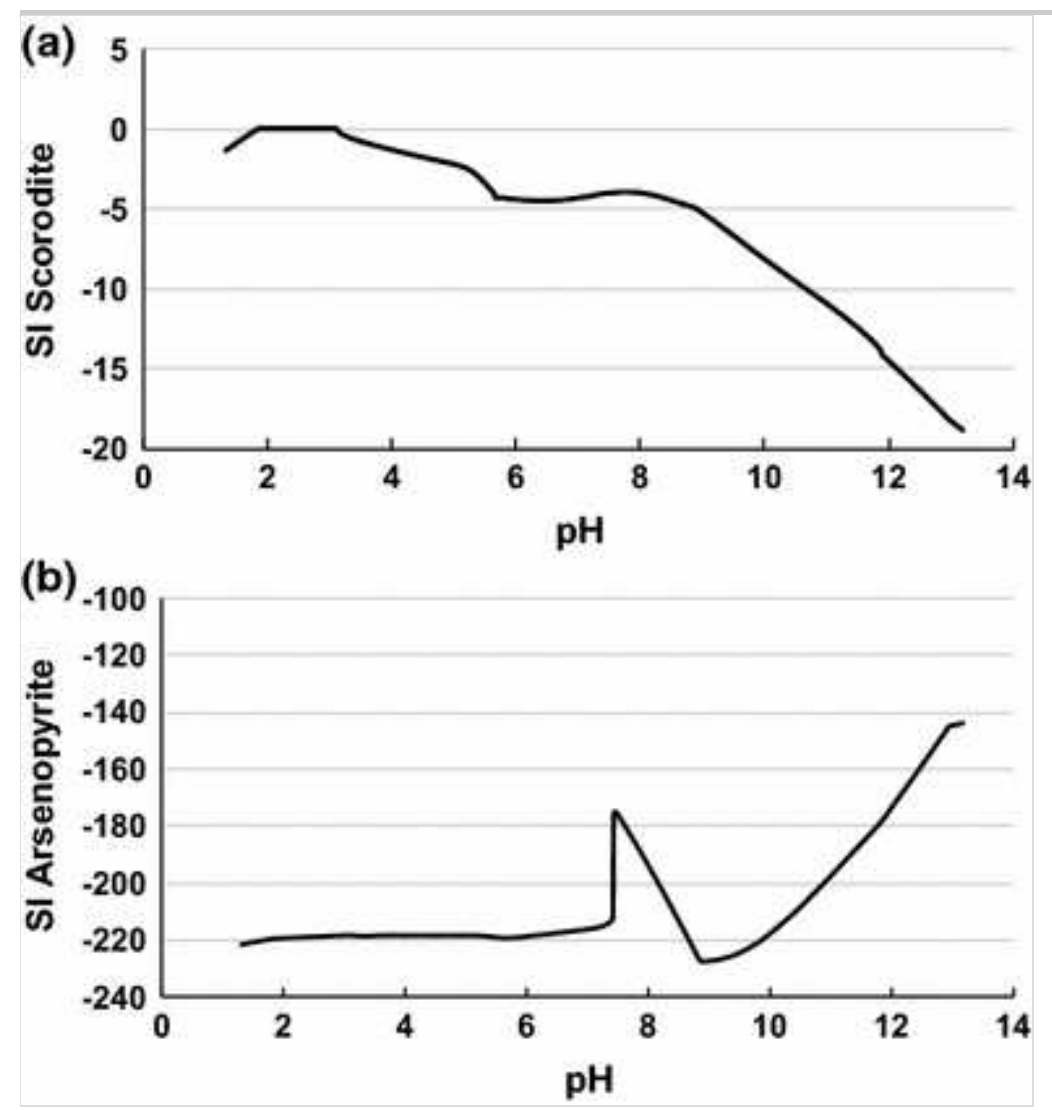

In PHREEQC modeling, scorodite was the only phase containing As that could possibly precipitate at low $\mathrm{pH}$. As stated by Paktunc and Bruggeman (2010), scorodite has its lowest solubility around $\mathrm{pH} 3$. In contrast, for $\mathrm{pH}$ less than 2 and greater than 6 , its solubility is quite high. It is reported in the literature that As may precipitate as secondary sulfides (orpiment, arsenic trisulfite or pyrite) in a reduced environment that causes the reduction of $\mathrm{SO}_{4}$ (Sracek et al. 2004). Given the oxidant conditions of the leaching test in the present study, $\mathrm{SO}_{4}$ reduction and consequently secondary sulfide precipitation can be excluded. 
In the experimental data, As concentration in solution decreased until pH 6 . Since scorodite precipitation alone cannot explain As behavior for $\mathrm{pH}$ higher than three, adsorption was taken into account. In fact, the model with adsorption (Model 2) was better correlated with As behavior, especially at neutral (6-7) and alkaline $\mathrm{pH}$. For $\mathrm{pH}$ lower than 3, modeling suggests that amorphous iron(III) hydroxide $\left(\mathrm{Fe}(\mathrm{OH})_{3}(\mathrm{am})\right)$ may be completely dissolved and that scorodite precipitation would remain the governing process.

In conclusion, modeling confirmed that As release is mainly controlled by adsorption on ferric hydroxide. High concentrations of As were attributed to the dissolution of iron oxyhydroxides, causing the release of arsenic initially associated with this phase. In the absence of SCM, As concentration in solution at neutral $\mathrm{pH}$ would be three orders of magnitude higher. Modeling also revealed the contribution of scorodite to explain As behavior at low $\mathrm{pH}$ $(<3)$.

\section{Conclusions and perspectives}

An As-contaminated soil collected from a gold mining site in France has been studied. In order to better understand the parameters controlling the potential release of As from contaminated soils into surface or ground-waters, an experimental methodology was developed that combined the use of leaching tests (single and sequential chemical extraction procedures) in conjunction with a mineralogical study. This experimental procedure was applied to contaminated soil samples collected from a gold mining site.

The results obtained indicated first that although As concentration in the considered soil was quite high, the release of As into deionized water was very limited in leaching tests. This was attributed primarily to the low solubility and the stability of the solid-bearing phases of As in the soil under slightly acidic natural conditions.

The multidisciplinary approach (leaching and mineralogy) developed in this work provided information on the nature of As fixation processes that may control As reactivity in the subsurface environment. It was observed that most of the As (72\%) appeared to be reversibly sorbed onto Fe phases in the soil particles, in particular Fe oxyhydroxides. These results indicated a potential risk of As mobilization over the long term under specific leaching conditions (i.e., pH or ORP gradient, chelation effect, etc.) which frequently occur in mining environments. Indeed, many factors can significantly affect the 
geochemical status of contaminated soils such as climate, fluctuating groundwater levels, periodic inundation, activity of microorganisms, vegetation, or deterioration of the physical properties of the substrate.

The role of adsorption in the control of dissolved As was supported by geochemical modeling. The retention of As at neutral $\mathrm{pH}$ seems to be governed by HFO adsorption, indicating that Fe oxyhydroxides dissolution is responsible for As release.

\section{Acknowledgments}

The authors are grateful to the Région Rhône-Alpes and the Association RE.CO.R.D. (Waste Research Cooperative Network, France) for financial support.

\section{References}

AFNOR (1996) Qualité des sols—Sols, sédiments—Mise en solution totale par attaque acide (NF X31-147). AFNOR, Paris

Alam MGM, Tokunaga S, Maekawa T (2001) Extraction of arsenic in a synthetic arsenic-contaminated soil using phosphate. Chemosphere 43(8):1035-1041. doi:10.1016/S0045-6535(00)00205-8

Azcue JM, Nriagu JO (1995) Impact of abandoned mine tailings on the arsenic concentrations in Moira Lake, Ontario. J Geochem Explor 52(1):81-89. doi:10.1016/0375-6742(94)00032-7

Baker DE, Chesnin L (1975) Chemical monitoring of soils for environmental quality and animal and human health. Adv Agro 27:305-375. doi:10.1016/S0065-2113(08)70013-0

Bayard R, Chatain V, Gachet C, Troadec A, Gourdon R (2006) Mobilisation of arsenic from a mining soil in batch slurry experiments under bio-oxidative conditions. Water Res 40(6):1240-1248. doi:10.1016/j.watres.2006.01.025

Biswas A, Gustafsson JP, Neidhardt H, Halder D, Kundu AK, Chatterjee D, Berner Z, Bhattacharya P (2014) Role of competing ions in the mobilization of arsenic in groundwater of Bengal Basin: Insight from surface complexation modeling. Water Res 55:30-39. 
doi:10.1016/j.watres.2014.02.002

Bodénan F, Baranger P, Piantone P, Lassin A, Azaroual M, Gaucher E, Braibant G (2004) Arsenic behaviour in gold-ore mill tailings, Massif Central, France: hydrogeochemical study and investigation of in situ redox signatures. Appl Geochem 19(11):1785-1800.

doi:10.1016/j.apgeochem.2004.03.012

Bolan N, Kunhikrishnan A, Thangarajan R, Kumpiene J, Park JE, Makino T, Kirkham MB, Scheckel K (2014) Remediation of heavy metal(loid)s contaminated soils-To mobilize or to immobilize? J Hazard Mater 266:141-166. doi:10.1016/j.jhazmat.2013.12.018

Bowell R (1994) Sorption of arsenic by iron oxides and oxyhydroxides in soils. Appl Geochem 9(3):279-286. doi:10.1016/0883-2927(94)90038-8

Boyle RW, Jonasson IR (1973) The geochemistry of arsenic and its use as an indicator element in geochemical prospecting. J Geochem Explor 2(3):251-296. doi:10.1016/0375-6742(73)90003-4

Carbonell-Barrachina A, Jugsujinda A, DeLaune RD, Patrick WH, Burló F, Sirisukhodom S, Anurakpongsatorn P (1999) The influence of redox chemistry and $\mathrm{pH}$ on chemically active forms of arsenic in sewage sludgeamended soil. Environ Int 25(5):613-618.

doi:10.1016/S0160-4120(99)00027-6

Carrillo-Chávez A, Salas-Megchún E, Levresse G, Muñoz-Torres C, PérezArvizu O, Gerke T (2014) Geochemistry and mineralogy of mine-waste material from a "skarn-type" deposit in central Mexico: modeling geochemical controls of metals in the surface environment. J Geochem Explor 144((Part Ał):28-36. doi:10.1016/j.gexplo.2014.03.017

Chatain V (2004) Characterization of arsenic and other inorganic constituents potential mobilization from soils collected from a gold mining site. Doctoral dissertation, INSA-Lyon, Lyon University, France

Chatain V, Sanchez F, Bayard R, Moszkowicz P (2003) Arsenic behavior in mining soil. J Phys-Paris IV 107(1):289-292. doi:10.1051/jp4:20030298

Chatain V, Bayard R, Sanchez F, Moszkowicz P, Gourdon R (2005a) Effect 
of indigenous bacterial activity on arsenic mobilization under anaerobic conditions. Environ Int 31(2):221-226. doi:10.1016/j.envint.2004.09.019

Chatain V, Sanchez F, Bayard R, Moszkowicz P, Gourdon R (2005b) Effect of experimentally induced reducing conditions on the mobility of arsenic from a mining soil. J Hazard Mater 122(1):119-128.

doi:10.1016/j.jhazmat.2005.03.026

Clozel B, Battaglia F, Conil P, Ignatiadis I (2002) Physical, chemical, and biological treatability of contaminated soils (Final report-BRGM/RP52065-FR). BRGM, Orléans

Coussy S, Benzaazoua M, Bussière B, Peyronnard O, Blanc D, Moszkowicz P, Malchère A (2010) Stabilization/solidification of arsenic in cemented paste backfill: geochemical modeling as a mineralogical characterization tool. In: Proceedings of the first International Stabilization/Solidification Technology forum, pp. 161-170

Drouhot S, Raoul F, Crini N, Crini N, Tougard, Druart C, Rieffel D, Lambert JC, Tête N, Giraudoux P, Scheifler R (2014) Responses of wild small mammals to arsenic pollution at a partialy remediated mining site in Southern France. Sci Total Environ 470-471:1012-1022

Dzombak DA, Morel FM (1990) Surface complexation modeling: hydrous ferric oxide. Wiley, New York

Flakova R, Zenisova Z, Sracek O, Kremar D, Ondrejkova I, Chovan M, Lalinska B, Fendekova M (2012) The behavior of arsenic and antimony at Pezinok mining site, southwestern part of the Slovak Republic. Environ Earth Sci 66:1043-1057

Gonzalez-Fernandez O, Queralt I, Manteca JI, Garcia G, Carvalho ML (2011) Distribution of metals in soils and plants around mineralized zones at Cartagena-La Unión mining district (SE, Spain). Environ Earth Sci 63(6):1227-1237

Huang YC (1994) Arsenic distribution in soils. In: Nriagu JO (ed) Arsenic in the environment-Part 1. Wiley, New York, pp 17-49

Hudson-Edwards KA, Schell C, Macklin MG (1999) Mineralogy and 
geochemistry of alluvium contaminated by metal mining in the Rio Tinto area, southwest Spain. Appl Geochem 14(8):1015-1030.

doi:10.1016/S0883-2927(99)00008-6

Hummel W, Berner U, Curti E, Pearson F, Thoenen T (2002) Nagra/PSI chemical thermodynamic data base 01/01. Nagra NTB 02-16, Nagra, Wettingen, Switzerland. http://www.nagra.ch/g3.cms/s_page/77900/s_name /shopengl/S_NAME/shopde/lang/EN

Jana U, Chassany V, Bertrand G, Castrec-Rouelle M, Aubry E, Boudsocq S, Laffray D, Repellin A (2012) Analysis of arsenic and antimony distribution within plants growing at an old mine site in Ouche (Cantal, France) and identification of species suitable for site revegetation. $\mathbf{J}$ Environ Manage 110:188-193

Jiang W, Zhang S, Shan XQ et al (2005) Adsorption of arsenate on soils. Part 2: modeling the relationship between adsorption capacity and soil physiochemical properties using 16 Chinese soils. Environ Pollut 138(2):285-289. doi:10.1016/j.envpol.2005.03.008

Kosson DS, van der Sloot HA, Sanchez F, Garrabrants AC (2002) An integrated framework for evaluating leaching in waste management and utilization of secondary materials. Environ Eng Sci 19(3):159-204. doi:10.1089/109287502760079188

Lumsdon DG, Meeussen JCL, Paterson E, Garden LM, Anderson P (2001) Use of solid phase characterisation and chemical modelling for assessing the behaviour of arsenic in contaminated soils. Appl Geochem 16(6):571-581. doi:10.1016/S0883-2927(00)00063-9

Matera V, Le Hecho I, Laboudigue A, Thomas P, Tellier S, Astruc M (2003) A methodological approach for the identification of arsenic bearing phases in polluted soils. Environ Pollut 126(1):51-64.

doi:10.1016/S0269-7491(03)00146-5

Navarro MC, Pérez-Sirvent C, Martínez-Sánchez MJ, Vidal J, Tovar PJ, Bech J (2008) Abandoned mine sites as a source of contamination by heavy metals: a case study in a semi-arid zone. J Geochem Explor 96(2-3):183-193. doi:10.1016/j.gexplo.2007.04.011 
Nordstrom DK, Parks GA (1987) Solubility and stability of scorodite, $\mathrm{FeAsO}_{4} \cdot 2 \mathrm{H}_{2} \mathrm{O}$ : discussion. Am Mineral 72(7-8):849-851

Paktunc D, Bruggeman K (2010) Solubility of nanocrystalline scorodite and amorphous ferric arsenate: implications for stabilization of arsenic in mine wastes. Appl Geochem 25(5):674-683.

doi:10.1016/j.apgeochem.2010.01.021

Parkhurst DL, Appelo C (1999) User's guide to PHREEQC (Version 2): a computer program for speciation, batch-reaction, one-dimensional transport, and inverse geochemical calculations

Peyronnard O, Blanc D, Benzaazoua M, Moszkowicz P (2009) Study of mineralogy and leaching behavior of stabilized/solidified sludge using differential acid neutralization analysis: Part II: use of numerical simulation as an aid tool for cementitious hydrates identification. Cement Concrete Res 39(6):501-509. doi:10.1016/j.cemconres.2009.03.012

Reith F, McPhail D (2007) Mobility and microbially mediated mobilization of gold and arsenic in soils from two gold mines in semi-arid and tropical Australia. Geochim Cosmochimi Ac 71(5):1183-1196.

doi:10.1016/j.gca.2006.11.014

Savage KS, Tingle TN, O’Day PA, Waychunas GA, Bird DK (2000) Arsenic speciation in pyrite and secondary weathering phases, Mother Lode gold district, Tuolumne County, California. Appl Geochem 15(8):1219-1244. doi:10.1016/S0883-2927(99)00115-8

Smedley P, Kinniburgh D (2002) A review of the source, behavior and distribution of arsenic in natural waters. Appl Geochem 17(5):517-568. doi:10.1016/S0883-2927(02)00018-5

Sracek O, Bhattacharya P, Jacks G, Gustafsson JP, von Brömssen M (2004) Behavior of arsenic and geochemical modeling of arsenic enrichment in aqueous environments. Appl Geochem 19(2):169-180.

doi:10.1016/j.apgeochem.2003.09.005

Tamaki S, Frankenberger WT Jr (1992) Environmental biochemistry of arsenic. Rev Environ Contam T 124:79-110 
van der Sloot H, Heasman L, Quevauviller P (1997) Harmonization of leaching/extraction tests. Studies in Environmental Science. Elsevier, Amsterdam

Yang JK, Barnett MO, Jardine PM, Basta NT, Casteel SW (2002)

Adsorption, sequestration, and bioaccessibility of As (V) in soils. Environ

Sci Technol 36(21):4562-4569. doi:10.1021/es011507s 